\title{
New Standard limits for Radionuclides in Foods
}

Department of Food Safety

Pharmaceutical \& Food Safety Bureau

Ministry of Health, Labour and Welfare 


\section{The concept of Current Provisional regulation Values}

The current provisional regulation values were established based on the concept shown below, in line with "index relating to the restriction of food intake" derived by the Nuclear Safety Commission under assumption of nuclear power plant accidents.

1) Set the annual maximum permissible dose from radioactive cesium in foods as $5 \mathrm{mSv}$ and assign to each food category.

2) Assuming that people continue to consume contaminated foods for a long time, derive regulatory values, based on the intakes according to food categories, so that the permissible dose is not exceeded.

Note: Apply the lowest levels - which are obtained by taking into consideration the intake and susceptibility of the groups of adults, young children, and infants - to all age groups.

e.g.) The setting method of current provisional regulation values for radioactive cesium

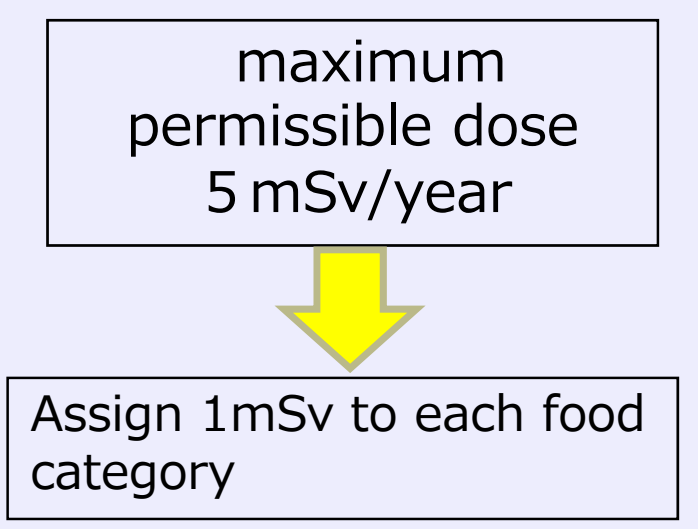

\begin{tabular}{l|c|}
\multicolumn{1}{c|}{} & \multicolumn{1}{c}{ Food category } \\
\cline { 2 - 2 } $1 \mathrm{mSv}$ & Drinking water \\
\cline { 2 - 2 } $1 \mathrm{mSv}$ & Milk, dairy products \\
\cline { 2 - 2 } $1 \mathrm{mSv}$ & Vegetables \\
\cline { 2 - 2 } $1 \mathrm{mSv}$ & Grains \\
\cline { 2 - 2 } $1 \mathrm{mSv}$ & Meat, eggs, fish, etc. \\
\cline { 2 - 2 } &
\end{tabular}

Calculate limit values $(\mathrm{Bq} / \mathrm{kg})$, taking into consideration the intake and susceptibility.

\begin{tabular}{|l|l|l|l|}
\hline Adults & $\begin{array}{l}\text { Young } \\
\text { children }\end{array}$ & Infants & Minimum \\
\hline$\underline{201}$ & 421 & 228 & $\underline{201}$ \\
\hline 1660 & 843 & $\underline{270}$ & $\underline{270}$ \\
\hline$\underline{554}$ & 1686 & 1540 & $\underline{554}$ \\
\hline$\underline{1110}$ & 3830 & 2940 & $\underline{1110}$ \\
\hline$\underline{664}$ & 4010 & 3234 & $\underline{664}$ \\
\hline
\end{tabular}

Regulation values

\begin{tabular}{|l|}
\hline $200 \mathrm{~Bq} / \mathrm{kg}$ \\
\hline $200 \mathrm{~Bq} / \mathrm{kg}$ \\
\hline $500 \mathrm{~Bq} / \mathrm{kg}$ \\
\hline $500 \mathrm{~Bq} / \mathrm{kg}$ \\
\hline $500 \mathrm{~Bq} / \mathrm{kg}$ \\
\hline
\end{tabular}




\section{Establishment of New Standard limits for Radionuclides in Food}

1. Concept of Review

O Based on current scientific knowledge, commodities that meet current provisional regulation values are considered to be safe, and in fact food safety is basically secured. However, to achieve further food safety and consumer confidence, Japan is planning to reduce maximum permissible dose from $5 \mathrm{mSv} /$ year to $1 \mathrm{mSv} /$ year.

O Establish the four categories of "Drinking water", "Infant foods" and "Milk", which are deemed to need special consideration, and "General foods" for other foods.

2. New standard limits

(Date of enforcement : April 1, 2012. Transitional measure applies to some commodities.)

OProvisional regulation values for radioactive cesium ${ }^{1}$

\begin{tabular}{|c|c|}
\hline Category & Limit \\
\hline Drinking water & 200 \\
\hline Milk, dairy products & 200 \\
\cline { 1 - 1 } Vegetables & \multirow{2}{*}{500} \\
\cline { 1 - 1 } Grains & \\
\cline { 1 - 1 } Meat, eggs, fish, etc. & \\
\cline { 1 - 2 }
\end{tabular}

\section{ONew standard limits for radioactive cesium ${ }^{2}$}

\begin{tabular}{|c|c|}
\hline Category & Limit \\
\hline Drinking water & 10 \\
\hline Milk & 50 \\
\hline General Foods & 100 \\
\hline Infant Foods & 50 \\
\hline
\end{tabular}

NOTE: 1 These values take into account the contribution of radioactive strontium

(Unit : $\mathrm{Bq} / \mathrm{kg}$ )

2 These limits take into account the contribution of radioactive strontium, pultonium etc. 


\section{The range of food categories}

\begin{tabular}{|c|c|c|}
\hline $\begin{array}{l}\text { Food } \\
\text { category }\end{array}$ & The reason to establish new standard limits & The range of foods \\
\hline $\begin{array}{l}\text { Drinking } \\
\text { water }\end{array}$ & $\begin{array}{l}1 \text { Water is essential for human life and there is } \\
\text { no substitution for water, and its consumption } \\
\text { is large. } \\
2 \text { WHO's guidance level for radioactive cesium in } \\
\text { drinking water is } 10 \mathrm{~Bq} / \mathrm{kg} \text {. } \\
3 \text { Strict management is possible for the } \\
\text { radionuclides in tap water. }\end{array}$ & $\begin{array}{l}\text { O Drinking water, water used for cooking and } \\
\text { tea drinks, which is substitute for water }\end{array}$ \\
\hline $\begin{array}{l}\text { Infant } \\
\text { Foods }\end{array}$ & $\begin{array}{l}\text { The Food Safety Commission pointed out that } \\
\text { "the susceptibility to radiation may be higher } \\
\text { in childhood than in adulthood." }\end{array}$ & $\begin{array}{l}\text { O Foods approved to be labeled as "fit for } \\
\text { infants" based on Article } 26 \text { Paragraph } 1 \text { of } \\
\text { the Health Promotion Law } \\
\text { O Foods and drinks sold as intended for infants }\end{array}$ \\
\hline Milk & $\begin{array}{l}1 \text { Children consume a lot. } \\
2 \text { Food Safety Commission pointed out that "a } \\
\text { susceptibility to radiation may be higher in } \\
\text { childhood than in adulthood." }\end{array}$ & $\begin{array}{l}\text { "Milk" and "milk drinks" refers to products } \\
\text { specified in Article } 2 \text { Paragraph } 1 \text { and } 40 \text { of } \\
\text { the Ministerial Ordinance concerning } \\
\text { Compositional Standards Etc. for Milk and } \\
\text { Milk Products. }\end{array}$ \\
\hline $\begin{array}{l}\text { General } \\
\text { Foods }\end{array}$ & $\begin{array}{l}\text { For the following reasons, foods other than given } \\
\text { above are categorized as "General Foods" } \\
1 \text { It is possible to make the influence of } \\
\text { individual differences in eating habits (deviation } \\
\text { of the foods to be consumed) minimal. } \\
2 \text { Regulation intelligible for people } \\
3 \text { Consistency with international views, such as } \\
\text { these of Codex Alimentarius Commission }\end{array}$ & O Foods other than given above \\
\hline
\end{tabular}




\section{The concept of radionuclides to be regulated (1)}

\section{- Radionuclides}

Targets to be regulated are all radionuclides which were placed on the trial calculation list of the Nuclear and Industrial Safety Agency as substances emitted by the Fukushima nuclear power plant accident, and whose halflife is over 1 year.

Note: Standard limits are not established for radioactive Iodine, which has a short half-life and has been no longer detected, and the for Uranium, whose level is the almost the same in the nuclear power plant site as in the nature environment.

\begin{tabular}{|l|c|}
\hline Regulated Radionuclides & Physical Half-life \\
\hline Cs-134 & 2.1 years \\
\hline Cs-137 & 30 years \\
\hline Sr-90 & 29 years \\
\hline Pu & 14 years or more \\
\hline Ru-106 & 374 days \\
\hline
\end{tabular}




\section{The concept of radionuclides to be regulated (2)}

\section{- The concept for establishment of new standard limits}

The new standard limits for radioactive cesium are established for effective dose of radionuclides (including $\mathrm{Sr}-90, \mathrm{Ru}-106, \mathrm{Pu}$ ) not to exceed $1 \mathrm{mSV} /$ year.

Because radionulides other than Cs-134 and Cs-137 require a longer time for measurement, following procedure is taken to establish new standard limits.

- Analyze the migration ratio of each radionuclide according to migration pathway, derive the contribution of radioactive cesium according to product and age categories, and establish standard limits for radioactive cesium so that the sum of effective dose not exceed $1 \mathrm{mSv} /$ year.

e.g.) The contribution of radionuclides other than radioactive cesium is about $12 \%$ (in case of people aged 19 and older)

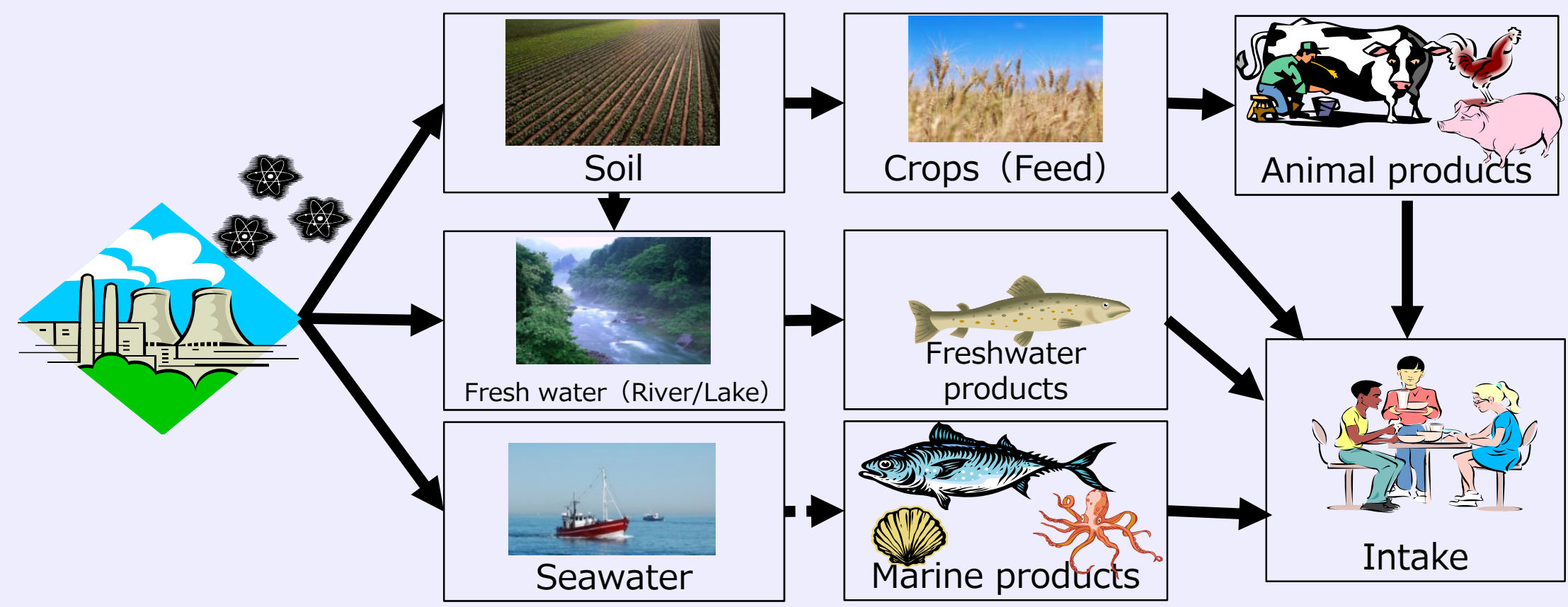




\section{The Concept of standard limit for "General Foods"}

\begin{tabular}{|c|c|c|c|c|}
\hline \multirow{3}{*}{$\begin{array}{c}\text { Operational } \\
\text { intervention level } \\
1 \mathrm{mSv} / \text { year }\end{array}$} & $\begin{array}{l}\text { mit values, } t \\
\text { version coeff }\end{array}$ & $\begin{array}{l}\text { king into } \\
\text { cient acc }\end{array}$ & $\begin{array}{l}\text { nsideration } \\
\text { ling to agec }\end{array}$ & \multirow{13}{*}{$\begin{array}{l}\text { Standard limit } \\
100 \mathrm{~Bq} / \mathrm{kg}\end{array}$} \\
\hline & Age category & Intake & $\begin{array}{l}\text { Limit value } \\
(\mathrm{Bq} / \mathrm{kg})\end{array}$ & \\
\hline & under 1 & Average & 460 & \\
\hline \multirow{10}{*}{$\begin{array}{l}\text { Determine the effective } \\
\text { dose to assign to } \\
\text { "General foods" }\end{array}$} & \multirow{2}{*}{$1-6$} & Male & 310 & \\
\hline & & Female & 320 & \\
\hline & \multirow{2}{*}{$7-12$} & Male & 190 & \\
\hline & & Female & 210 & \\
\hline & \multirow{2}{*}{$13-18$} & Male & 120 & \\
\hline & & Female & 150 & \\
\hline & \multirow{2}{*}{19 and older } & Male & 130 & \\
\hline & & Female & 160 & \\
\hline & pregnant & Female & 160 & \\
\hline & \multicolumn{2}{|c|}{ Minimum } & 120 & \\
\hline
\end{tabular}

<Effective dose for "Drinking water"=Standard limit for "Drinking water" (Bq/kg)

$\times$ Intake of drinking water according to age category $\times$ Dose Coefficient according to age category $>$

- In line with WHO's guidance level for radioactive cesium in drinking water, the standard limit for "Drinking water" is established as $10 \mathrm{~Bq} / \mathrm{kg}$, and the effective dose as about $0.1 \mathrm{mSv} /$ year.

- The effective dose to assign to "General foods" is determined as about $0.9 \mathrm{mSv} / \mathrm{year}$ by subtracting the effective dose for "Drinking water"(about $0.1 \mathrm{mSv} /$ year) from the operational intervention level(1mSv/year)

- Limit values are calculated by dividing this effective dose by the intake and conversion coefficient according to age category. (On the assumption that $50 \%$ of the marketed foods are contaminated.) 


\section{The range of "Infant Foods"}

\section{Category}

- Foods approved to be labeled as "fit for infants" based on Article 26

Paragraph 1 of the Health Promotion Law

\section{The range of foods}

- Infant formula

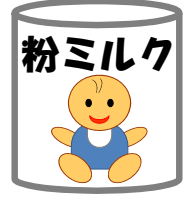

- Foods and drinks sold as intended for infants

$\rightarrow$ Foods which can be recognized by consumers as products intended for infants from the appearance and labeling of outer package, etc.
- Formulated milk powder for young children

(Including follow up milk etc.)

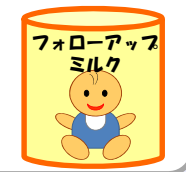

- Foods for young children (snacks etc.)

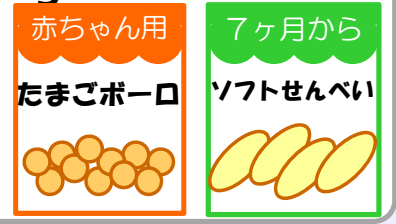

- Baby foods

(Weaning foods etc.)

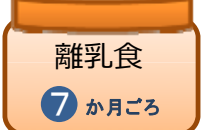

- Drinks for young children The limit for "Drinking water" applies to tea drinks

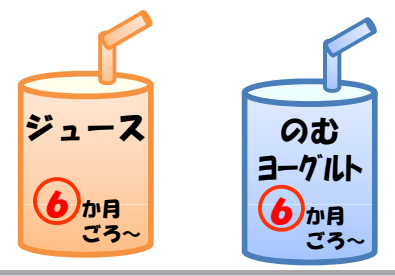

\section{- Others}

jelly-type sugarcoat, dietary supplement for infants etc.
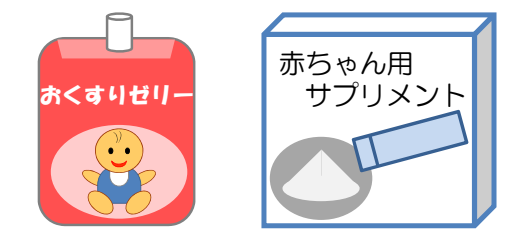


\section{<Foods included in "Milk" category>}

The "Milk" category covers milk and milk drinks.

Milk drinks are drink products which are made mainly of milk as the main ingredient, and they include those which are recognized by consumers as similar kinds of drinks to milk and processed milk.

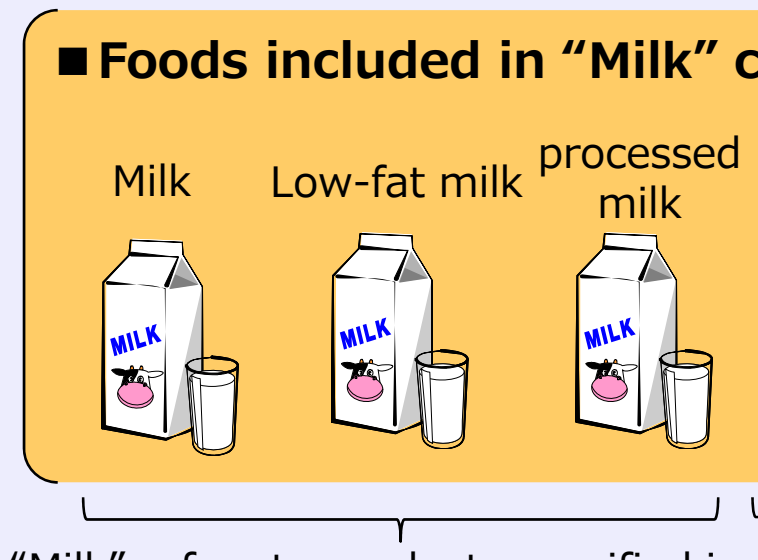

"Milk" refers to products specified in the Ministerial Ordinance concerning Compositional Standards Etc. for Milk and Milk Products.

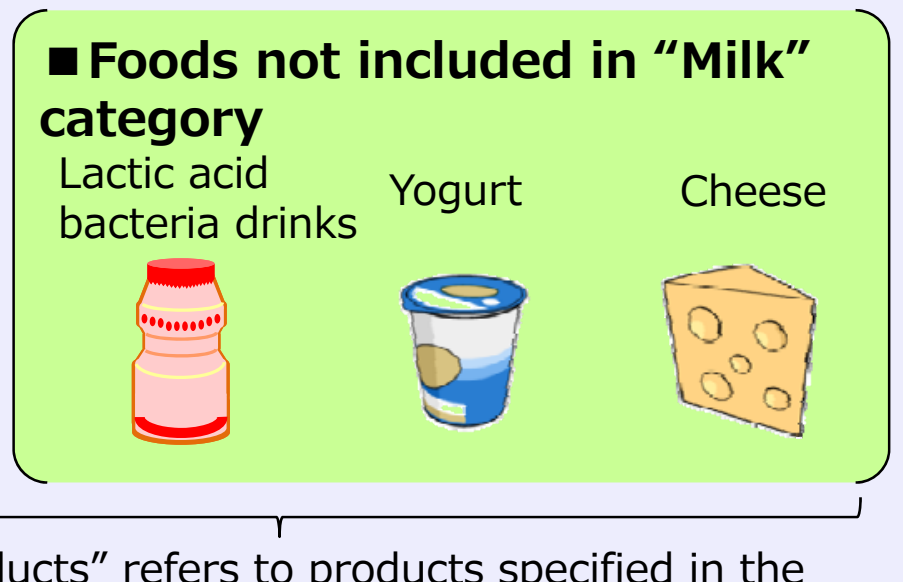

"Milk products" refers to products specified in the Ministerial Ordinance concerning Compositional Standards Etc. for Milk and Milk Products.

- Since "Milk" and "Infant foods" are categories provided in consideration for children, the standard limit for them is established as a level that is not affected even if all of the marketed foods are contaminated.

$\rightarrow$ "50 Bq/ $/ \mathrm{kg}$ " which is half of new standard limit for "General foods" $(100 \mathrm{~Bq} / \mathrm{kg})$ applies to "Milk" and "Infant foods". 


\section{Application of standard limits to foods manufactured/processed}

\section{- Basic Concept}

In principle, processed foods are subject to the standard limit for "General foods". The standard limit applies to the various stages of products on a case by case basis, for example, to the finished products or ingredients. For the foods given in 1 and 2 below, the standard limit applies to products in a ready-to-eat state based on the view of Codex Commission.

1 Dry foods that are intended to be consumed in a reconstituted state, such as dried products of mushrooms, seaweeds, fish \& shellfish and vegetables etc.

$\rightarrow$ The standard limit for "General foods" applies to ingredients (in a natural state) and reconstituted products.

Notes: For foods that are intended to be consumed in a dried state, such as nori(dried laver), niboshi(dried sardines), dried cuttlefish, raisin, etc., the standard limit for "General foods" applies to ingredients (in a natural state) and finished products (in a dry state).

2 Foods that are consumed after brewing process, such as tea leaves, and foods that are produced through extraction process, such as vegetable oils, like rice oil.

$\rightarrow$ There is a big difference in form between ingredients and products before consumption. For these foods, the standard limit does not apply to ingredients. For tea leaves, the standard limit for "Drinking water" applies to a liquid extract obtained after brewing process. For edible oils, which are obtained through extraction from rice bran or oil seeds, the standard limit for "General foods" applies to oil as finished product. 


\section{Transitional measures}

- Food safety is ensured for commodities that meet current provisional regulation values for radionuclides. Transitional measures are set for some commodities (rice, beef, soybean) which needs a certain period of preparation to prevent any confusion in distribution at the time of shift to new standard limits.

- The Government of Japan gives thorough explanation to consumers and producers about food safety and reasons why these foods are targets of the measures.

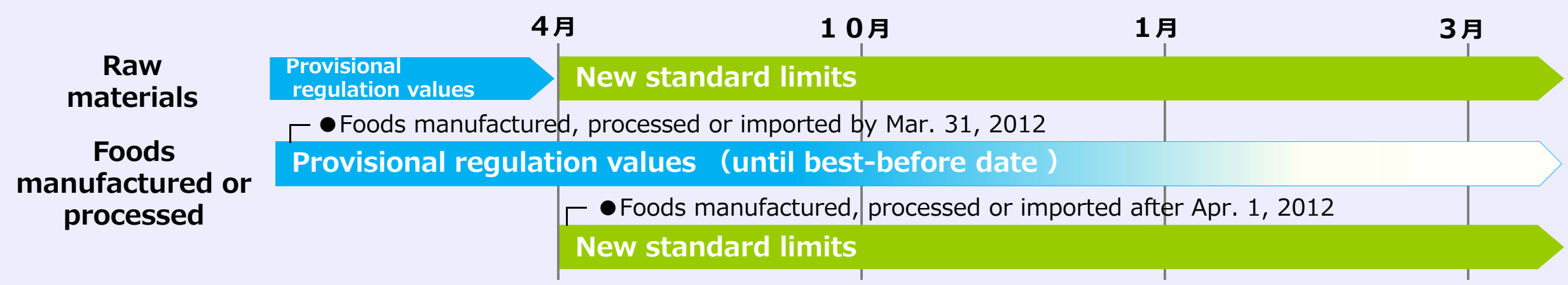

$<$ Transitional measure applies to following commodities $>$

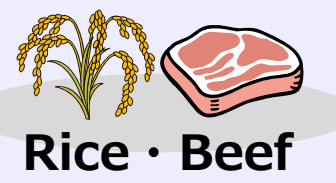

Products manufactured or processed from rice or beef and their import

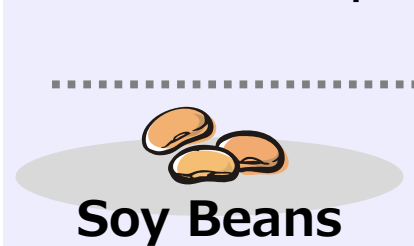

\section{Soy Beans}

Products manufactured or processed from soy

beans and their import

- Foods manufactured, processed or imported by Sep. 30, 2012

Provisional regulation values (until best-before date)

- Foods manufactured, processed or imported New standard limits after Oct. 1, 2012

Provisional regulation values (until December 31, 2012)

Foods manufactured, processed or imported by Dec. 31, 2012 Provisional regulation values (until best-before date ) 


\section{Estimation of effective dose on assumption that people continue to consume foods}

that contain radionuclides at the maximum levels of the new standard limits.

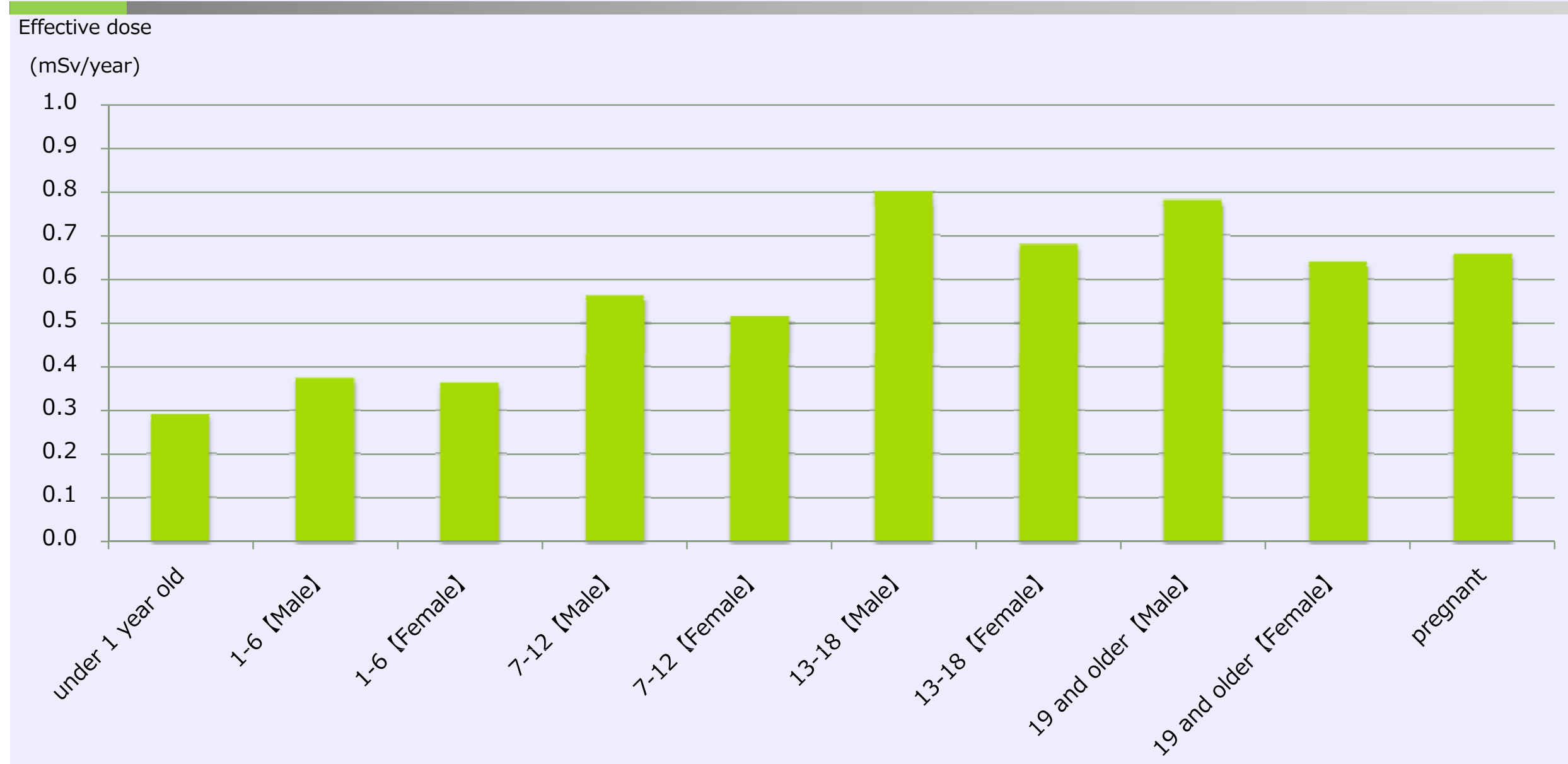

- An actual effective dose is considered to be much smaller, since it is highly unlikely to consume foods contains radioactive cesium at the maximum level of new standard limits through the year.

Note: The actual effective dose is estimated at about $0.04 \mathrm{mSv} /$ year(median), when the estimation is done using the average intake for all ages.

※On the assumption that $50 \%$ of "General foods" and $100 \%$ of "Drinking water", "Milk" and "Infant foods" are contaminated. 


\section{Estimation of effective dose from radionuclides in foods}

O Estimation of effective dose from radioactive cesium based on new standard limit.

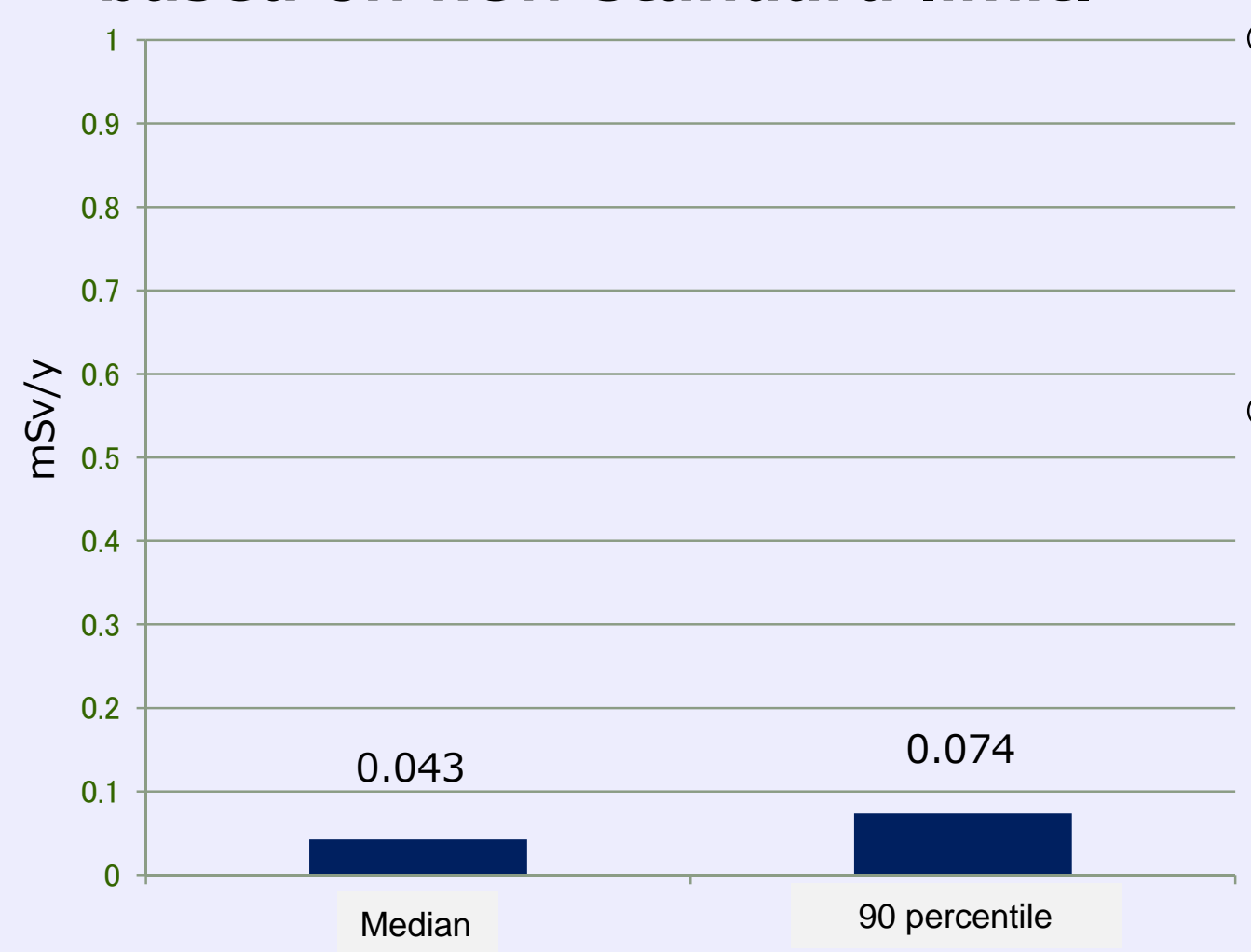

O Estimation is based on the monitoring data of the radionuclides in foods.

(Released by MHLW; August 1 November 16, 2011)

OThe actual effective dose under new standard limits are estimated to be smaller than operational intervention level (1mSv/year) on the assumption that people continue to consume the national average intake(all ages) of foods for one year that contain radioactive cesium at the median concentration or 90

Notes) percentile concentration.

o For non-detection data, detection limits( up to $20 \mathrm{~Bq} / \mathrm{kg}$ ) for Cs-134 and Cs-137 were used.

When the detection limit was not shown, $5 B q / \mathrm{kg}$ was applied to food groups for which the ratio of ND was not less than $80 \%, 10 \mathrm{~Bq} / \mathrm{kg}$ was applied to food groups for which the ratio of ND was $60 \%$ to $80 \%$, and $20 \mathrm{~Bq} / \mathrm{kg}$ to others. This was taken into consideration the view of GEMS/food of WHO.

Offective dose from radionulclides other than radioactive cesium are added to these estimates in reality, because these values are estimated only from radioactive cesium. 


\section{Estimation of effective dose from radionuclides in foods}

The intake of $\mathrm{K}-40$ (natural radionuclide) is comparable to the result obtained from samples collected before the Tokyo Electric Power Company's Fukushima Dai-ichi Nuclear Power Plant accident.

\section{OEstimation of annual effective dose from K-40, Cs-134 and Cs-137}

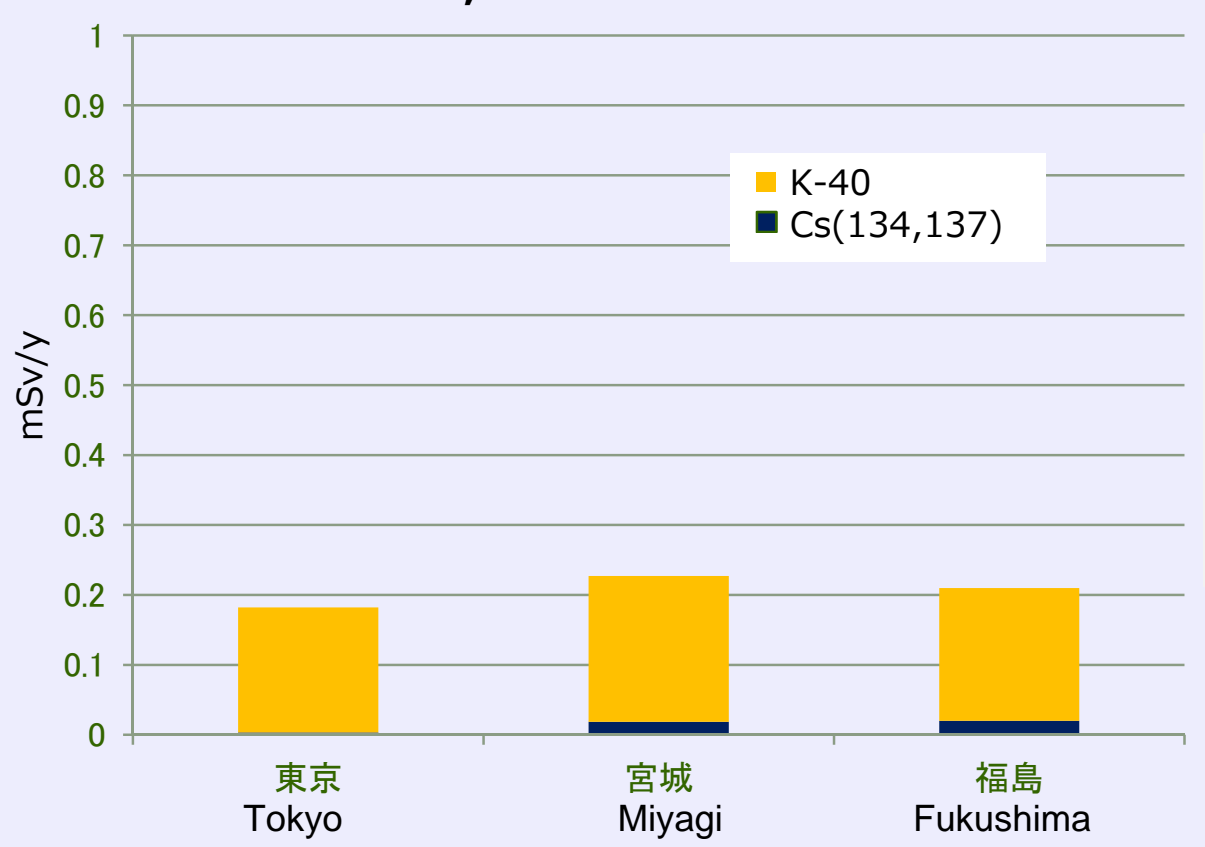

OEstimation of annual effective dose from natural radionuclides (2008)

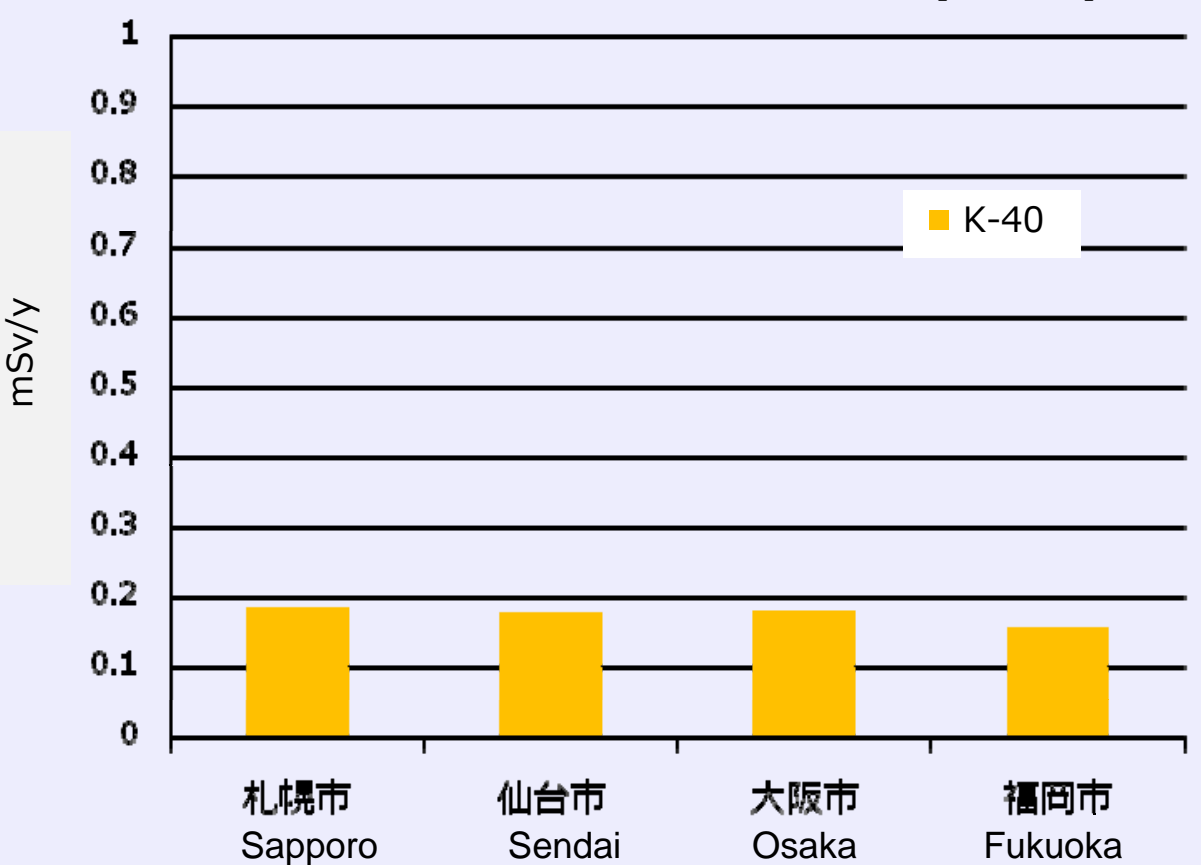

OFoods were purchased in Tokyo, Miyagi and Fukushima Prefectures in September and November 2011.

For perishable foods purchased in Miyagi and Fukushima Prefectures, local grown products were selected, wherever possible. If impossible, the products produced in neighboring prefectures were purchased.

OBased on the National Health and Nutrition Examination Survey(2007), the test samples were prepared by mixing all foods purchased and used with drinking water. Then, radionuclides(I-131, Cs134, Cs-137, and K-40) were analyzed using a germanium semiconductor detector, and annual effective dose(mSv/man/year) for general eating patterns were estimated. 


\section{Progress of the review of regulation values}

\section{Notification of provisional regulation values in foods (MHLW) (Mar. 17, 2011)}

The Minister of Health, Labour and Welfare requested food safety risk assessment of radionuclides to Food Safety Commission (Mar. 20)

O Report of food safety risk assessment by Food Safety Commission (Oct. 27) 1

The Minister Komiyama talked about a future fundamental plan in a ministerial conference. ( Oct. 28)

$\bigcirc$ Consultation to Pharmaceutical Affairs and Food Sanitation Council (MHLW)

Arrangement of a point of argument by Subcommittee \& Section meeting of Pharmaceutical Affairs and Food Sanitation Council (Oct. 31) 1

The discussion on new standard limits by section meeting of Pharmaceutical Affairs and Food Sanitation Council (Nov. 24) 12

Proposal standard limits are created by section meeting of Pharmaceutical Affairs and Food Sanitation Council (Dec. 22)

Consultation \& Report to/by Radiation Council (MEXT) (Consultation :Dec. 27, Under deliberations)

Public comment (Jan. 6, 2004 - Feb. 4) , WTO/TBT notification ( Jan.17 - Feb. 10, 2012),

Risk communication (Jan. 16 - Feb. 28, 2012) etc.

Report by Pharmaceutical Affairs and Food Sanitation Council (MHLW)

Promulgation of standard limits (Mar. 15, 2012)

Enforcement of standard limits (Apr 1, 2012) 